\title{
Potential of the essential oil from Pimenta pseudocaryophyllus as antimicrobial agent
}

ÉRIKA YOKO SUZUKI ${ }^{1}$

EDILENE BOLUTARI BAPTISTA ${ }^{1}$

ANTÔNIO MÁRCIO RESENDE DO CARMO 2

MARIA DAS GRAÇAS AFONSO MIRANDA

CHAVES $^{2}$

ELIZABETH LEMOS CHICOUREL

NÁDIA REZENDE BARBOSA RAPOSO ${ }^{1 *}$

${ }^{1}$ NUPICS, Federal University of Juiz de Fora, Brazil

${ }^{2}$ NUPITE, Federal University of Juiz de Fora, Brazil

\begin{abstract}
This study evaluated the effectiveness of the essential oil of Pimenta pseudocaryophyllus in inhibiting the growth of the main bacteria responsible for bad perspiration odor (Staphylococcus epidermidis, Proteus hauseri, Micrococcus yunnanensis and Corynebacterium xerosis). The chemical profile of the essential oil was evaluated by high-resolution gas chromatography (HR-GC) and four constituents were identified, eugenol being the major component ( $88.6 \%)$. The antimicrobial activity was evaluated by means of the turbidimetric method, using the microdilution assay. The minimum inhibitory concentration (MIC) values of the essential oil ranged from 500 to $1,000 \mu \mathrm{g} \mathrm{mL} \mathrm{m}^{-1}$. Scanning electron microscope (SEM) observations confirmed the physical damage and morphological alteration of the test bacteria treated with the essential oil, reference drugs and eugenol. The findings of the study demonstrated that this essential oil can be used in the formulation of personal care products.
\end{abstract}

Keywords: Pimenta pseudocaryophyllus (Myrtaceae), essential oil, eugenol, antimicrobial activity, scanning electron microscopy

The human body odor is the unpleasant smell caused by mixing of sweat and bacteria on the skin. Personal care products are used to mask and reduce body odor caused by the microbial metabolism of sweat. Some personal care products contain antimicrobial agents that decrease the number of bacteria and consequently avoid the unpleasant smell of the microbial secretion compounds (1). However, some antimicrobial chemicals are associated with adverse effects such as hypersensitivity, allergic reaction, immunity suppression, and microbial resistance that can emerge with its indiscriminate use. In this context, it is necessary to search for other substances that could serve as alternatives to such products (2).

Essential oils are widely used for cosmetic applications such as perfumes, cosmetics, soaps and deodorants (3). They contain a mixture of many compounds (terpenes, alcohols, acetones, phenols, acids, aldehydes, and esters), which are functional components in phar-

\footnotetext{
* Correspondence; e-mail address: nadiafox@gmail.com
} 
maceuticals (4). The usage of cosmetics and personal care products with natural ingredients has been growing at an average rate of about $15 \%$ over the last few years (5).

Several studies of the genus Pimenta have been run due to its potential biological functions. The species Pimenta pseudocaryophyllus belongs to the family Myrtaceae (6) found in the Atlantic Rain Forest and sporadically in Cerrado (Brazil) (7). According to Paula et al. (8), differences in essential oil constituents between different regions of Brazil were observed indicating the possibility of chemical polymorphism in this plant species. The essential oil from P. pseudocaryophyllus has various applications, such as flavoring, in cosmetics and perfumes, and insecticidal. In addition, it has pharmacological importance due to its analgesic, antibacterial and sedative properties $(3,9)$.

The aim of the present study was to evaluate the antimicrobial activity of the essential oil from Pimenta pseudocaryophyllus (Gomes) L.R. Landrum against the main bacteria responsible for bad perspiration odor.

\section{EXPERIMENTAL}

\section{Essential oil}

The essential oil from Pimenta pseudocaryophyllus (lot CRAVOCA02) was obtained from Lazlo Aromatologia Ltda (Brazil). Eugenol (99 \%) was obtained from Sigma-Aldrich (USA).

\section{Gas chromatography}

To get an insight into the main chemical constituents of the essential oil, an aliquot was subjected to analysis by high-resolution gas chromatography (HR-GC) (HP 5890 (Hewlett-Packard, USA) equipped with a flame ionization detector. A BP-1 (SGE) $30 \mathrm{~m} \times$ $0.25 \mathrm{~mm}$ column was used and a column temperature gradient (initial $=60^{\circ} \mathrm{C}$; then an increase of $3{ }^{\circ} \mathrm{C} \mathrm{min}-1$ up to $220^{\circ} \mathrm{C}$ ), injector (split of $1 / 50$ ) and detector at $220^{\circ} \mathrm{C}$. The carrier gas used was hydrogen $\left(2 \mathrm{~mL} \mathrm{~min}^{-1}\right)$ and the injection volume was $1 \mu \mathrm{L}$. Samples were diluted to $0.5 \%(V / V)$ in chloroform. Identification of essential oil components was based on the retention times of sample components and a mixture of $n$-alkanes from $\mathrm{C}_{10}-\mathrm{C}_{18}$; the calculated Kovats index was compared with the available literature (10).

\section{Antimicrobial activity}

Microorganisms. - Micrococcus yunnanensis (ATCC 7468), Proteus hauseri (ATCC 13315) and Staphylococcus epidermidis (ATCC 12228) were obtained from the American Type Culture Collection (Manassas, USA). Corynebacterium xerosis (IAL105) was obtained from the Adolfo Lutz Institute Culture Collection (São Paulo, Brazil).

Antimicrobial screening and minimum inhibitory concentration (MIC). - Inhibition of microorganism growth was determined by the turbidimetric method using a microdilution assay in a sterile 96-well microplate (Sarstedt, Germany) (11). Each well contained $100 \mu \mathrm{L}$ of the essential oil ( 62.5 to $1,000 \mu \mathrm{g} \mathrm{mL} \mathrm{m}^{-1}$ eugenol) and $100 \mu \mathrm{L}$ of brain heart infusion (BHI) for C. xerosis or Mueller Hinton broth (MHB) for the others, with the bacteria representing 
approximately $4 \times 10^{3}$ colony-forming units (CFU) $\mathrm{mL}^{-1}$. Microplates were incubated at $35^{\circ} \mathrm{C}$ for $24 \mathrm{~h}$. After that, $30 \mu \mathrm{L}$ of aqueous solution of $0.01 \mathrm{mg} \mathrm{mL}^{-1}$ resazurin (Sigma-Aldrich) was added into each well and the microplate was reincubated for four hours. The MIC values were determined by the change in color, with the highest dilution remaining blue indicating the MIC. Chloramphenicol $\left(0.025-250 \mu \mathrm{g} \mathrm{mL}^{-1}\right)$ and neomycin $(0.0125-125 \mu \mathrm{g}$ $\mathrm{mL}^{-1}$ ) (both from Galena, Brazil) were used as reference drugs. In addition, the assay was also done with eugenol $\left(62.5\right.$ to $\left.1,000 \mu \mathrm{g} \mathrm{mL}^{-1}\right)$, which was identified as a major component of the essential oil. Tests were carried out in triplicate.

Minimum bactericidal concentration (MBC). - To determine the minimum bactericidal concentration value, wells showing the absence of growth in the MIC assay were identified and $20 \mu \mathrm{L}$ of each well content was transferred to tubes with tryptone soy broth (TSB). The tubes were incubated at $35^{\circ} \mathrm{C}$ for $24 \mathrm{~h}$. The $M B C$ value was regarded as the lowest concentration of the essential oil where no visible growth was observed.

Scanning electron microscopy analysis. - SEM was used to investigate morphological changes in the strains of interest submitted to the treatment with the essential oil, chloramphenicol and neomycin. SEM was carried out by a method adapted from Gao et al. (2). Bacterial cells were incubated for $24 \mathrm{~h}$ in $\mathrm{MHB}$ (S. epidermidis, P. hauseri, M. yunnanensis) or $\mathrm{BHI}$ (C. xerosis) at $35^{\circ} \mathrm{C}$. The suspension was treated with essential oil, eugenol or the reference drug (chloramphenicol or neomycin) at MIC value, and then the samples were reincubated at $35{ }^{\circ} \mathrm{C}$ for $24 \mathrm{~h}$. After incubation, cells were harvested by centrifugation for $10 \mathrm{~min}$ at 5,000xg and transferred onto slides. The cells were fixed with $2.5 \%$ glutaraldehyde (Sigma-Aldrich) for $12 \mathrm{~h}$. After that, the slides were washed with $0.1 \mathrm{~mol} \mathrm{~L}^{-1}$ phosphate buffer solution ( $\mathrm{pH} 7.4$ ), dehydrated with increasing concentrations of ethanol (50 to $99 \%$ ) at an interval of 20 min between each exchange, and dried at room temperature. The slides were mounted onto stubs using double-sided carbon tape and then metallized in Balzers Union FL - 9496 (Balzers, Germany) with two nm of gold for two min. They were then analyzed in the scanning electron microscope JSM 5310 (Jeol, Japan) under $25 \mathrm{~kW}$ of power.

\section{RESULTS AND DISCUSSION}

According to Bakkali et al. (12), essential oils are characterized by two or three major components at fairly high concentrations (20-70\%) compared to other components present in trace amounts. In the present work, eugenol was the major component (88.6\%) found in the essential oil of P. pseudocaryophyllus. This finding is in agreement with a previous report, which stated that the major components of the essential oils of the genus Pimenta mainly consisted of phenylpropanoids (eugenol, methyleugenol, transmethyl isoeugenol, timol), monoterpene (1,8-cineol), monoterpenic aldehydes (neral, geranial) and alcohol derivatives (geraniol, linalol, $\alpha$-terpineol) (7). Custodio et al. (3) also demonstrated that eugenol (92.6\%) was the major component in the essential oil of pseudocaryophyllus, which also contained methyleugenol, terpinen-4-ol, o-cymene and E-caryophyllene. However, Lima et al. (9) obtained different results from two specimens of P. pseudocaryophyllus collected from different locations. For a specimen collected from Paranapiacaba, 4-methyleugenol $(94.6 \%)$ represented the main component and according to the authors, the observed differences in antimicrobial activity could be due to variation of the major component. 
The compounds identified in this work are listed in Table I according to their elution order (Fig. 1). In total, four constituents were identified, representing $95.1 \%$ of all components in the essential oil of $P$. pseudocaryophyllus. Results showed eugenol (88.6 \%) as the major compound in the essential oil, followed by $\beta$-caryophyllene eugenyl acetate and 1,8-cineole.

The essential oil of P. pseudocaryophyllus exhibited bacteriostatic activity against all the bacteria tested, except for $S$. epidermidis. The data also reveal the bacteriostatic activity of eugenol against all bacteria and bactericidal activity against $P$. hauseri ATCC 13315 and $C$. xerosis IAL105. The MIC values of the essential oil and eugenol ranged from $500 \mu \mathrm{g} \mathrm{mL}^{-1}$ to $1,000 \mu \mathrm{g} \mathrm{mL}^{-1}$ (Table II). Possible minor effects of the other components of the essential oil, such as $\beta$-caryophylene, eugenyl acetate and 1,8-cineole, need yet to be elucidated.

Paula et al. (8) showed antimicrobial activity of essential oils of P. pseudocaryophyllus against S. epidermidis ATCC 12229 and M. yunnanensis ATCC 9341. However, these authors

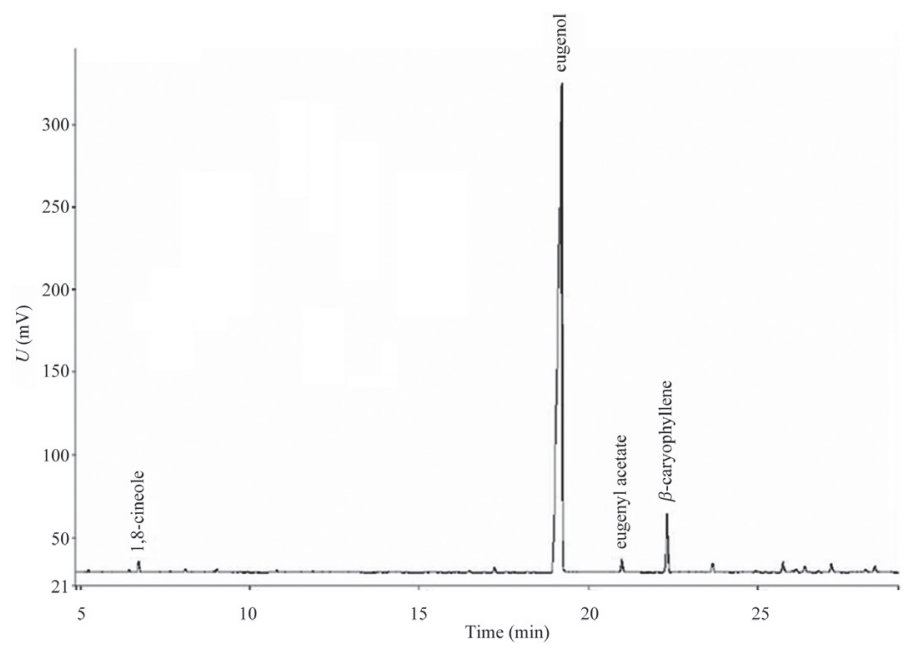

Fig. 1. Chromatographic profile of the essential oil from P. pseudocaryophyllus. Peaks lower than $0.1 \%$ were not identified.

Table I. Chemical composition of the essential oil from P. pseudocaryophyllus

\begin{tabular}{cccc}
\hline No & Compound & Content $(\%)$ & Kovats index \\
\hline 1 & 1,8 -cineole & 0.7 & 1019 \\
2 & eugenol & 88.6 & 1266 \\
3 & eugenol acetate & 1.0 & 1284 \\
4 & $\beta$-caryophyllene & 4.8 & 1297 \\
& total & 95.1 & \\
\hline
\end{tabular}

The components not listed are present in amounts smaller than $0.1 \%$. 
Table II. Minimal inhibitory concentrations (MIC) and minimum bactericidal concentrations (MBC)

\begin{tabular}{lcccccccc}
\hline Microorganism & $\begin{array}{c}\text { Essential oil } \\
(\mu \mathrm{g} \mathrm{mL})^{-1}\end{array}$ & $\begin{array}{c}\text { Eugenol } \\
\left(\mu \mathrm{mL}^{-1}\right)\end{array}$ & $\begin{array}{c}\text { Chloramphenicol } \\
\left(\mu \mathrm{mL}^{-1}\right)\end{array}$ & $\begin{array}{c}\text { Neomycin } \\
\left(\mu \mathrm{mL}^{-1}\right)\end{array}$ \\
\hline & MIC & MBC & MIC & $M B C$ & $M I C$ & $M B C$ & $M I C$ & $M B C$ \\
\hline S. epidermidis ATCC 12228 & - & - & 1,000 & - & 2.5 & 25 & 1.25 & 1.25 \\
P. hauseri ATCC 13315 & 500 & - & 500 & 1,000 & 2.5 & 25 & 12.5 & 12.5 \\
M. yunnanensis ATCC 7468 & 500 & - & 1,000 & - & 2.5 & 25 & 12.5 & 125 \\
C. xerosis IAL105 & 1,000 & - & 1,000 & 1,000 & 25 & 250 & 1.25 & 1.25 \\
\hline
\end{tabular}

${ }^{a}$ On the basis of eugenol.

- Not detected at all tested concentrations (62.5 to $1,000 \mu \mathrm{g} \mathrm{mL} \mathrm{m}^{-1}$ of eugenol or essential oil).

Concentrations higher than $1,000 \mu \mathrm{g} \mathrm{mL}^{-1}$ were not tested.

studied two different chemotypes (E-methyl isoeugenol and citral) and not eugenol. The authors suggest that $E$-methyl isoeugenol differs structurally from eugenol.

Leite et al. (13) evaluated the effectiveness of eugenol in inhibiting S. epidermidis ATCC 12228 and S. epidermidis SSI 1 and they showed antibacterial effect with MIC of $5 \mu \mathrm{L} \mathrm{mL}^{-1}$ for both microorganisms. Similar results were reported by Hammer and Heel (26), who found the MIC value of eugenol of $0.2 \%(V / V)$ against S. epidermidis ATCC 12228. In addition, Oyedemi et al. (14) demonstrated the bactericidal effect of eugenol against Proteus hauseri ATCC $43071[\mathrm{MIC}=0.5 \%(\mathrm{~V} / \mathrm{V})]$ and suggested that the cytoplasmic membrane was a target for eugenol action.

Low $M B C$ values of reference drugs were found while the essential oil only demonstrated bacteriostatic activity. Although the MIC values of the essential oil of P. pseudocaryophyllus were higher than those of chloramphenicol and neomycin, it may be an alternative bacteriostatic agent. This makes it an alternative to be used in cosmetic and personal care formulations, also due to its pleasant and attractive aroma.

No studies of the essential oil of P. pseudocaryophyllus demonstrating the antimicrobial activity by SEM have been done so far. However, Devi et al. (15) studied the antibacterial activity of its chemotaxonomic marker, eugenol, and its mechanism against Salmonella typhi. SEM examination revealed that rough surface morphology and shrinkage of cells were apparent in the cells treated with eugenol, when compared to the untreated ones. Our SEM observations confirmed the physical damage and morphological alteration to the tested bacteria treated with the essential oil, eugenol and reference drugs (chloramphenicol and neomycin). Bacterial cells treated with the essential oil and reference drugs demonstrated a destructive effect on the morphology of cell membrane, showing wrinkled abnormalities on the cells, cleft and pore formation. Some cells showed damage such as disruption or deformities in cell membranes. Cells exposed to eugenol also showed altered morphology compared to the control group. The SEM images are shown in Fig. 2. Such morphological features in bacterial cells might be due to the lysis of the cell membrane. 

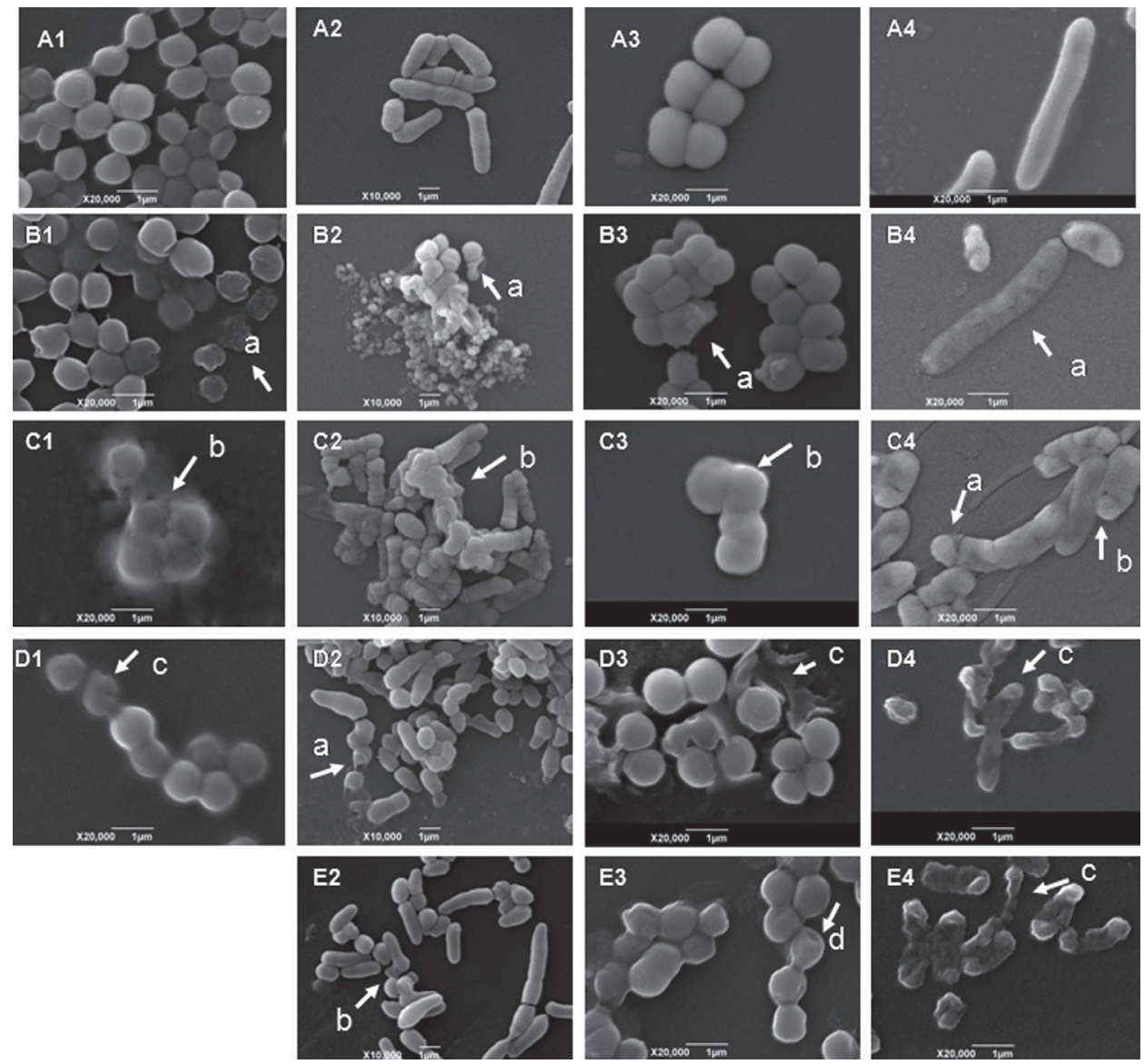

Fig. 2. SEM images of bacterial cells: A) not exposed to substances of interest, B) exposed to chloramphenicol, C) exposed to neomycin, D) exposed to eugenol, E) exposed to essential oil of P. pseudocaryophyllus. 1 - S. epidermidis ATCC 12228, 2 - C. xerosis IAL 105, 3 - M. yunnanensis ATCC 7468, $4-P$. hauseri ATCC 13315. a - destroyed cell, b - aggregated/deformed cells, c - disruption and lysis of membrane integrity, $\mathrm{d}$ - shows pore formation.

\section{CONCLUSIONS}

The findings of the present study demonstrated that the essential oil of Pimenta pseudocaryophyllus has a bacteriostatic activity against the main microorganisms responsible for bad perspiration odor, probably due to its high content of eugenol. Therefore, this essential oil can be used in the formulations of personal care products.

Acknowledgements. - The authors acknowledge the financial support from CAPES, CNPq, FAPEMIG. 


\section{REFERENCES}

1. S. K. Pandey and K. Kim, Human body-odor components and their determination, Trends Anal. Chem. 30 (2011) 784-796; DOI: 10.1016/j.trac.2010.12.005.

2. C. Gao, C. Tian, Y. Lu, J. Xu, J. Luo and X. Guo, Essential oil composition and antimicrobial activity of Sphallerocarpus gracilis seeds against selected food-related bacteria, Food Control 22 (2011) 517-522; DOI: 10.1016/j.foodcont.2010.09.038.

3. D. L. Custódio, R. P. Burgo, B. Moriel, A. M. Barbosa, M. I. Rezende, J. F. S. Daniel, J. P. Pinto, E. Bianchini and T. J de Faria, Antimicrobial activity of essential oils from Pimenta pseudocaryophyllus and Tynanthus micranthus, Braz. Arch. Biol. Techn. 53 (2010) 1363-1369; DOI: 10.1590/S151689132010000600013.

4. P. S. Negi, Plant extracts for the control of bacterial growth: Efficacy, stability and safety issues for food application, Int. J. Food Microbiol. 156 (2012) 7-17; DOI: 10.1016/j.ijfoodmicro.2012.03.006.

5. P. M. Reddy, M. Gobinath, K. M. Rao, P. Venugopalaiah and N. Reena, A review on importance of herbal drugs in cosmetics, IJAPN 1 (2011) 121-139; DOI: 20111213-P-madhuri-Reddy-Et-Al-IJAPN.

6. L. R. Landrum and M. L. Kawasaki, The genera of Myrtaceae in Brazil: an illustrated synoptic treatment and identification keys, Brittonia 49 (1997) 508-536; DOI: 10.2307/2807742.

7. J. A. M. de Paula, J. R. de Paula, M. T. Freitas Bara, P. H. Ferri, S. C. Santos and L. H. S. Silva, Chemical differences in the essential oil of Pimenta pseudocaryophyllus (Gomes) L. R. Landrum leaves from Brazil, J. Essent. Oil Res. 22 (2010) 555-557; DOI: 10.1080/10412905.2010.9700398.

8. J. A. M. de Paula, M. R. R. Silva, M. P. Costa, D. G. A. Diniz, F. A. S. Sá, S. F. Alves, E. A. Costa, R. C. Lino and J. R. Paula, Phytochemical analysis and antimicrobial, antinociceptive, and anti-inflammatory activities of two chemotypes of Pimenta pseudocaryophyllus (Myrtaceae), Evid. Based Complement. Alternat. Med. (2012) 1-15; DOI: 10.1155/2012/420715.

9. M. E. L. Lima, I. Cordeiro, M. C. M. Young, M. E. G. Sobra and P. R. H. Moreno, Antimicrobial activity of the essential oil from two specimens of Pimenta pseudocaryophyllus (Gomes) 1. r. Landrum (Myrtaceae) native from São Paulo state - Brazil, Pharmacologyonline 3 (2006) 589-593; DOI: 10.1590/S1516-89132010000600013.

10. R. P. Adams, Identification of Essential Oil Components by Gas Chromatography/mass Spectrometry, $4^{\text {rd }}$ ed., Allured Bussiness Media, Carol Stream (IL) 2009.

11. F. Candan, M. Unlu, B. Tepe, D. Daferera, M. Polissiou, A. Sökmen and A. Akpulat, Antioxidant and antimicrobial activity of essential oil and methanol extracts of Achillea millefolium subsp. millefolium Afan. (Asteraceae), J. Ethnopharmacol. 87 (2003) 215-220; DOI: 10.1016/S0378-8741(03)00149-1.

12. F. Bakkali, S. Averbeck, D. Averbeck and M. Idaomar, Biological effects of essential oils - A review, Food Chem. Toxicol. 46 (2008) 446-475; DOI: 10.1016/j.fct.2007.09.106.

13. A. M. Leite, E. O. Lima, E. L. Souza, M. F. F. M. Diniz, V. N. Trajano and I. A. Medeiros, Inhibitory effect of $\beta$-pinene, $\alpha$-pinene and eugenol on the growth of potential infectious endocarditis causing Gram-positive bacteria, Rev. Bras. Cienc. Farm. 43 (2007); DOI: 10.1590/S1516-93322007000100015.

14. A. S. Oyedemi, O. I. Okoh, L. V. Mabinya, G. Pirochenva and A. J. Afolayan, The proposed mechanism of bactericidal action of eugenol, $\alpha$-terpineol and $\gamma$-terpinene against Listeria monocytogenes, Streptococcus pyogenes, Proteus vulgaris and Escherichia coli, Afr. J. Biotechnol. 8 (2009) 1280-1286.

15. K. P. Devi, S. A. Nisha, R. Sakthivel and S. K. Pandian, Eugenol (an essential oil of clove) acts as an antibacterial agent against Salmonella typhi by disrupting the cellular membrane, J. Ethnopharmacol. 130 (2010) 107-115; DOI: 10.1016/j.jep.2010.04.025. 